\title{
Iron (III)-Selective Sensor Based on Modified Glassy Carbon Electrode
}

\author{
N. Mecheri ${ }^{1}$, \\ 1,Laboratory of Sensors, Instrumentations and Process (LCIP), Institute of Science and Technology, \\ University of Khenchela, Khenchela, Algeria
}

Corresponding author's e-mail chimie.nassira@yahoo.fr , <mechri.nacira@univ-khenchela.dz

\begin{abstract}
:
The aim of this work is intended to make a comparison between the effects of the presence of potassium ferricyanide $\left(\mathrm{K}_{3}\left[\mathrm{Fe}(\mathrm{CN})_{6}\right]\right)$ / potassium ferrocyanide $\left.\mathrm{K}_{4}\left[\mathrm{Fe}(\mathrm{CN})_{6}\right]\right)$ and the absence of any redox couple for iron (III) determination in aqueous solution using modified Glassy Carbon Electrode. Benzo-18-crown-6 is employed as ionophores for preparing PVC-based membrane sensors selective to iron (III), plasticized with Di-n-octyl phthalate, Tetrabutylammonium tetraphenylborate was used as additive.

The measurements performed and characterized by square wave voltammetry methods. Agents were optimized for iron (III) stripping analysis and optimal condition was frequency of $20 \mathrm{~Hz}$, step potential of $6 \mathrm{mV}$, amplitude of $40 \mathrm{mV}$, the modified glassy carbon electrode immersed in standard solutions of $\mathrm{Fe}(\mathrm{III})$ at $\mathrm{PH} 2.0$.The measurements are performed in $0.1 \mathrm{M} \mathrm{NaNO}_{3}$ and $0.1 \mathrm{M} \mathrm{HCl}(\mathrm{pH} 7)$. The square wave voltammograms showed a sharp peak around positive potentials $+0.260 \mathrm{~V}$ that was used for construction of the calibration curve in a work range from $10^{-10}$ until $10^{-6} \mathrm{~mol} \mathrm{~L}^{-1}$ of iron, exhibiting a linear correlation coefficient of 0.99 , a detection limit of $10^{-10} \mathrm{~mol} \mathrm{~L} \mathrm{~L}^{-1}$ and sensibility of $9.87 \mu \mathrm{A} / \mathrm{mol} \mathrm{L}^{-1}$, especially, those obtained by the presence of redox couple better than the absence of external redox.
\end{abstract}

Key words: square wave voltammetry, Iron (III) determination, Sensor, benzo-18-crown-6, PVC membrane sensor

\section{Introduction}

It is well known that iron is very important for environmental studies because is the metal in the first transition series [1].

In this paper we present the comparison between the effects of the presence of potassium ferricyanide $\left(\mathrm{K}_{3}\left[\mathrm{Fe}(\mathrm{CN})_{6}\right]\right)$ / potassium ferrocyanide $\mathrm{K}_{4}\left[\mathrm{Fe}(\mathrm{CN})_{6}\right]$ ) Redox Couple and the absence of any external redox for iron (III) determination in aqueous solution using modified Glassy Carbon Electrode.

Benzo-18-crown-6 is employed as ionophores for preparing PVC-based membrane sensors selective to iron (III), plasticized with Di-n-octyl phthalate,Tetrabutylammonium tetraphenylborate was used as additive.

Agents were optimized for iron (III) stripping analysis and optimal condition was frequency of $20 \mathrm{~Hz}$, step potential of $6 \mathrm{mV}$, amplitude of m40
$\mathrm{V}$, the modified glassy carbon electrode immersed in standard solutions of $\mathrm{Fe}(\mathrm{III})$ at $\mathrm{PH}$ 2.0 .The measurements are performed in $0.1 \mathrm{M}$ $\mathrm{NaNO}_{3}$ and $0.1 \mathrm{M} \mathrm{HCl}(\mathrm{pH} 7)$. The modified glassy carbon electrode immersed in standard solutions of $\mathrm{Fe}(\mathrm{III})$ at $\mathrm{PH} 2.0$.

\section{Results and Discussions}

We observe that the presence of ionophore in the polymeric membrane induce the stability and lead to the best response with optimized PVC; Di-n-octyl phthalate; TBATPB and benzo18-crown-6 wt.\% ratio of $29 ; 67 ; 2$ and 2 respectively.

Figure 1.depict the SWV performance of Fe (III) in $0.1 \mathrm{M} \mathrm{NaNO}_{3}$ and $0.1 \mathrm{M} \mathrm{HCl}(\mathrm{pH} 7)$ and the calibration curve for $\mathrm{Fe}$ (III) selective electrode in the absence of any external redox The related linear regression equation was: 
ip/ $\mu \mathrm{A}=3.08 \mathrm{C} \mathrm{Fe}(\mathrm{III}) / \mathrm{mol} . \mathrm{L}^{-1}+4,56$ and correlation coefficient was $R^{2}=0.99$. The detection limit of this electrode was $10^{-8} \mathrm{~mol}$ $\mathrm{L}^{-1}$.

Figure 2 depicts the SWV performance of $\mathrm{Fe}$ (III) in $0.1 \mathrm{M} \mathrm{NaNO}_{3}$ and $0.1 \mathrm{M} \mathrm{HCl}(\mathrm{pH} 7)$ and the calibration curve for $\mathrm{Fe}$ (III) selective electrode in the presence of potassium ferricyanide $\left(\mathrm{K}_{3}\left[\mathrm{Fe}(\mathrm{CN})_{6}\right]\right)$ / potassium ferrocyanide $\left.\mathrm{K}_{4}\left[\mathrm{Fe}(\mathrm{CN})_{6}\right]\right)$.

The peak currents were extracted and plotted versus concentration (Fig 2). The related linear regression equation was:

$\mathrm{ip} / \mu \mathrm{A}=7.78 \mathrm{C} \mathrm{Fe}(\mathrm{III}) / \mathrm{mol} \cdot \mathrm{L}^{-1}+4,81$

and correlation coefficient was $R^{2}=0.99$. The detection limit of this electrode was $10^{-10} \mathrm{~mol}$ $\mathrm{L}^{-1}$.

The working electrode was prepared by mixing $2 \mathrm{mg}$ ionophore, $67 \mathrm{mg}$ Di-n-octyl phthalate, $29 \mathrm{mg}$ of Polyvinyl chloride and $2 \mathrm{mg}$ of TBATPB.

It shoud be mentioned that the accuracy of data obtained by the presence of potassium ferricyanide $\left(\mathrm{K}_{3}\left[\mathrm{Fe}(\mathrm{CN})_{6}\right]\right)$ / potassium ferrocyanide $\mathrm{K}_{4}\left[\mathrm{Fe}(\mathrm{CN})_{6}\right]$ ) is better than those obtained by the absence of redox couple. The reason of this interesting behaviour is that when solutions of $\mathrm{Fe}^{3+}$ and $\left[\mathrm{Fe}(\mathrm{CN})_{6}\right] 3$ ) are mixed.

The iron is low spin and facilely reduced to the linked ferrocyanide ion $\left[\mathrm{Fe}(\mathrm{CN})_{6}\right]^{4-}$, which is a ferrous $\left(\mathrm{Fe}^{2+}\right)$ derivative. This redox couple is reversible and necessitates no action or fraction of $\mathrm{Fe}-\mathrm{C}$ bonds [2].

$$
\left[\mathrm{Fe}(\mathrm{CN})_{6}\right]^{3-}+e^{-} \rightarrow\left[\mathrm{Fe}(\mathrm{CN})_{6}\right]^{4-} \text {. }
$$

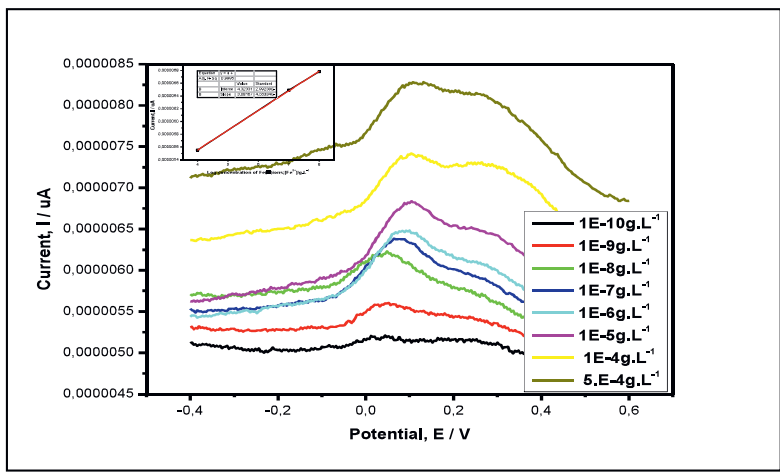

Fig. 1. SWV obtained on GC electrode after immersion in standard solutions of $\mathrm{Fe}(\mathrm{III})$ at $\mathrm{PH} 2$; the square wave conditions are step potential $6 \mathrm{mV}$ and frequency $20 \mathrm{~Hz}$. The measurements are performed in $0.1 \mathrm{M} \mathrm{NaNO}_{3}$ and $0.1 \mathrm{M} \mathrm{HCl}(\mathrm{pH} 7)$; in the absence of any external redox.

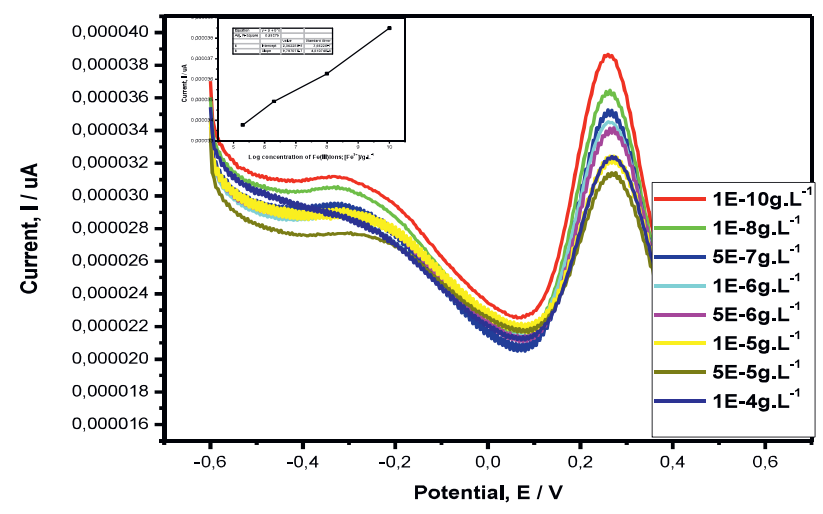

Fig. 2.SWV obtained on GC electrode after immersion in standard solutions of $\mathrm{Fe}(\mathrm{III})$ at $\mathrm{PH} 2$; the square wave conditions are step potential $6 \mathrm{mV}$ and frequency $20 \mathrm{~Hz}$. The measurements are performed in $0.1 \mathrm{M} \mathrm{NaNO}$ and $0.1 \mathrm{M} \mathrm{HCl}(\mathrm{pH} \mathrm{7})$; in the presence of potassium ferricyanide ( $\mathrm{K} 3[\mathrm{Fe}(\mathrm{CN}) 6])$ / potassium ferrocyanide $\left.\mathrm{K}_{4}\left[\mathrm{Fe}(\mathrm{CN})_{6}\right]\right)$ Redox Couple.

\section{Conclusions}

Iron (III)-Selective Sensor Based on Modified Glassy Carbon Electrode was elaborated.

The measurements performed and characterized by square wave voltammetry methods. The comparison between the effects of the presence of potassium ferricyanide $\left(\mathrm{K}_{3}\left[\mathrm{Fe}(\mathrm{CN})_{6}\right]\right)$ / potassium ferrocyanide $\left.\mathrm{K}_{4}\left[\mathrm{Fe}(\mathrm{CN})_{6}\right]\right)$ and the absence of any external redox couple were studied .The results demonstrated that sensor could be used for the determination of $\mathrm{Fe}(\mathrm{III})$ in the absence and in the presence of redox couple, the better results in the presence of potassium ferricyanide $\left(\mathrm{K}_{3}\left[\mathrm{Fe}(\mathrm{CN})_{6}\right]\right)$ / potassium ferrocyanide $\left.\mathrm{K}_{4}\left[\mathrm{Fe}(\mathrm{CN})_{6}\right]\right)$ Redox Couple, because $\mathrm{Fe}(\mathrm{III})$ was reduced to $\mathrm{Fe}(\mathrm{II})$ leaving the surface, it will be seen that in the absence of redox couple have smaller slopes. The preparation of the electrode is simple and the membrane composition including (PVC; Di-n-octyl phthalate; TBATPB and benzo-18-crown- 6 wt. \% ratio of $29 ; 67 ; 2$ and 2 respectively).

\section{References}

[1] H. Ali Zamani, Materials Science and Engineering C 32 (2012) 564-568.

[2] F. Scholz (ed.), Electroanalytical Methods, 2nd ed., DOC Springer- Verlag Berlin Heidelberg 2010. 